\title{
MARKET BASKET ANALYSIS (MBA) PADA SITUS WEB E-COMMERCE ZAKIYAH COLLECTION
}

\author{
Ari Muzakir \\ Fakultas Ilmu Komputer, Program Studi Teknik Informatika \\ Universitas Bina Darma \\ Email: arimuzakir@binadarma.ac.id \\ Laili Adha \\ Fakultas Ilmu Komputer, Program Studi Teknik Informatika \\ Universitas Bina Darma \\ Email: laili.adha@binadarma.ac.id
}

\begin{abstract}
ABSTRAK
E-commerce menghubungkan antara produsen dengan produsen, produsen dengan konsumen, konsumen dengan produsen, konsumen dengan konsumen. Untuk mengimplementasi e-commerce dalam mendukung bisnis organisasi perlu di perhatikan 5 komponen utama yaitu ; pengembangan produk, promosi, transaksi online, product delivery dan after sales support. Hal ini yang tengah diterapkan pada Zakiyah Collection. Zakiyah Collection bergerak dibidang penjualan aneka macam kain khas Palembang seperti songket, blongket,tanjung, dan lain sebagainya. Untuk melakukan analisis terhadap pangsa pasar yang ada agar dapat bersaing dengan toko online lainnya dilakukan dengan strategi pemasaran dengan menggunakan pendekatan market basket analysis (MBA). MBA merupakan salah satu teknik dari data mining yang digunakan untuk menentukan produk-produk manakah yang akan dibeli oleh pelanggan secara bersamaan dengan melakukan analisa terhadap daftar transaksi pelanggan. Dengan mengetahui produk-produk tersebut, maka sebuah sistem e-commerce dapat membuat maupun mengembangkan sebuah sistem customer profiles dan dapat menentukan layout katalog pelanggannya sendiri. Model pengembangan sistem yang dilakukan menggunakan prototype dimana pelanggan dan pengguna akan dilibatkan secara langsung dalam proses ini. Hasil akhir dalam penelitian ini adalah berupa analisis data transaksi menggunakan market basket analysis dengan dilakukan 4 kali kombinasi produk yang berdasarkan nilai support $\mathrm{x}$ confidence terbesar dengan hasil berupa angka-angka kemungkinan transasksi yang berkaitan dengan produk yang dijual. Jika dengan menggunakan 1 kali kombinasi, maka didapatkan blongket dengan nilai support sebesar 0.5625 . Jika dilakukan 2 kali kombinasi diperoleh kombinasi blongket dan songket dengan nilai support 0.375.
\end{abstract}

Kata kunci: e-commerce, market basket analysis, association rules.

\begin{abstract}
E-commerce links between producers and manufacturers, producers with consumers, consumers with producers, consumers with consumers. To implement e-commerce in support of the organization's business needs to consider five main components namely; product development, promotion, online transactions, product delivery and after sales support. It is being applied to Zakiyah Collection. Zakiyah Collection engaged in the sale of various kinds of fabrics such as typical Palembang songket, blongket, capes, and so forth. To conduct an analysis of the existing market share in order to compete with other online stores do with marketing strategy by using the approach of market basket analysis (MBA). MBA is one of data mining techniques are used to determine which of the products will be purchased by the customer together with the analysis of the list of customer transactions. By knowing these products, it is an e-commerce system can create and develop a system of customer profiles and can determine their own customers the catalog layout. Model development were performed using prototype systems where the customer and the user will be directly involved in this process. The final result of this research is in the form of transaction data analysis using market basket analysis to be done four times combination products based on the support $x$ greatest confidence with the results of the numbers transasksi possibilities related to the product being sold. If using one time the combination, then the value obtained blongket with the support of 0.5625. If done 2 times combination obtained blongket and songket combination with support at 0375 values.
\end{abstract}

Keywords: e-commerce, market basket analysis, association rules. 


\section{PENDAHULUAN}

Dewasa ini, perkembangan teknologi mengalami kemajuan yang sangat pesat.Salah satunya adalah teknologi komputer. Komputer merupakan alat bantu yang sekarang ini banyak digunakan oleh manusia, baik untuk menyelesaikan permasalahan yang dihadapi maupun menyelesaikan sebuah pekerjaan. Selain itu komputer juga dapat menjadi alat komunikasi, caranya yaitu dengan menggunakan fasilitas internet. Saat ini internet bukanlah hal yang asing bagi masyarakat, sebagian dari mereka sudah mengerti bagaimana cara mengakses dan menggunakan internet. Dengan internet mereka dapat melakukan komunikasi dengan orang-orang di seluruh dunia, mencari informasi yang aktual bahkan dapat melakukan pembelanjaan secara online yang dikenal dengan istilah $e$-commerce.

Secara umum e-commerce merupakan suatu cara berbelanja atau berdagang secara online yang memanfaatkan fasilitas internet. [5] Ecommerce merupakan perdagangan yang dilakukan secara elektronik dimana bentuk transaksi perdagangan baik membeli atau menjual dilakukan pada jaringan internet. e-commerce adalah kegiatan-kegiatan bisnis yang menyangkut konsumen (consumers), manufaktur (manufactures), service providers dan pedagang perantara (intermediaries) dengan menggunakan jaringan-jaringan komputer (computer networks) yaitu internet. Hal ini konsep yang sedang dijalankan di Zakiyah Collection Palembang.

Zakiyah Collection merupakan salah satu toko atau butik yang menjual berbagai macam jenis pakaian atau kain khas Palembang seperti songket,blongket, blongsong tanjung, dan lain sebagainya. Butik yang beralamat di Jl.K.H. Azhari No.136 RT.06 RW.05 13 Ulu Plaju Palembang selain menyediakan bahan untuk pakaian juga secara langsung menjadi pusat pembuatan songket, blongsong, blongket, dan tanjung.

Pada saat ini sistem penjualan pada Zakiyah Collection masih dilakukan secara langsung ke pengguna, dimana para calon pembeli yang ingin melakukan pemesanan atau pembelian harus datang langsung atau melalui telepon. Selain penjualan di toko atau butik Zaskia Collection, bahan-bahan kain khas Palembang ini juga didistribusikan di toko-toko lain di kota Palembang dan sekitarnya. Dengan adanya e-commerce ini, diharapkan para pelanggan nantinya dapat memperoleh kemudahan dalam memilih dan memesan barang yang mereka inginkan, kapan saja dan di mana saja mereka berada, tanpa harus datang langsung ke Zakiyah Collection. Selain itu juga web e-commerce ini menggunakan market basket analysis (MBA) sebagai pendekatan dalam analisis pangasa pasar. MBA merupakan salah satu teknik dari data mining yang digunakan untuk menentukan produk-produk manakah yang akan dibeli oleh pelanggan secara bersamaan dengan melakukan analisa terhadap daftar transaksi pelanggan.

Dalam proses pengembangan e-commerce tersebut dibutuhkan sebuah metode pengembangan sistem yang digunakan sebagai acuan dalam proses pengembangan. Metode yang digunakan adalah menggunakan prototyping. Cakupan aktivitas dari prototyping model terdiri dari :

1) Mendefinisikan objektif secara keseluruhan dan mengidentifikasi kebutuhan yang sudah diketahui.

2) Melakukan perancangan secara cepat sebagai dasar untuk membuat prototype.

3) Menguji coba dan mengevaluasi prototype dan kemudian melakukan penambahan dan perbaikan-perbaikan terhadap prototype yang sudah dibuat.

\section{METODOLOGI PENELITIAN}

Metode penelitian yang digunakan dalam penelitian ini adalah metode deskriptif. Dimana penelitian deskriptif adalah suatu bentuk penelitian yang ditujukan untuk mendeskripsikan fenomena-fenomena yang ada, baik fenomena alamiah maupun fenomena buatan manusia. Fenomena itu bisa berupa bentuk, aktivitas, karakteristik, perubahan, hubungan, kesamaan, dan perbedaan antara fenomena yang satu dengan fenomena lainnya [4].

Metode pengembangan sistem atau metode implementasi yang digunakan dalam penelitian ini adalah Prototyping. Penggunaan metode prototyping dilakukan karena pengembang dan pelanggan dapat saling berinteraksi selama proses pembuatan. Interaksi antara pengembang dan pelanggan untuk mendefinisikan secara umum apa yang dikehendakinya tanpa menyebutkan secara detail output apa saja yang dibutuhkan, pemrosesan dan data-data apa saja yang dibutuhkan. Sebaliknya disisi pengembang kurang memperhatikan efesiensi algoritma, kemampuan sistem operasi dan interface yang menghubungkan manusia dan komputer. Dibawah ini adalah diperlihatkan pada gambar 1 dari proses prototyping model: 


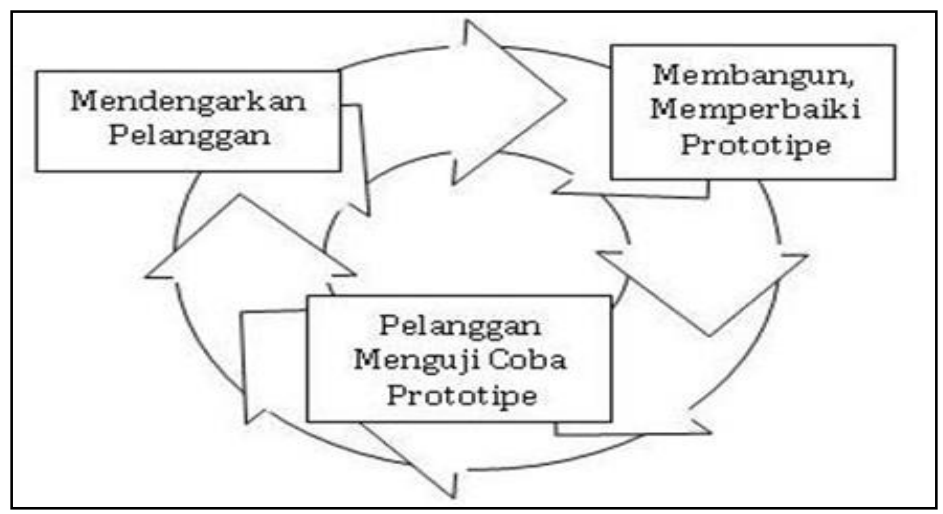

Gambar 1. Proses prototyping model

Istilah market basket analysis sendiri datang dari kejadian yang sudah sangat umum terjadi di dalam pasar swalayan, yakni ketika para konsumen memasukkan semua barang yang mereka beli ke dalam keranjang (basket) yang umumnya telah disediakan oleh pihak swalayan itu sendiri. Informasi mengenai produk-produk yang biasanya dibeli secara bersama-sama oleh para konsumen dapat memberikan "wawasan" tersendiri bagi para pengelola toko atau swalayan untuk menaikkan laba bisnisnya [1].

Dalam melakukan analisis market basket pada penelitian ini menggunakan association rule mining. Association rule mining adalah suatu prosedur untuk mencari hubungan antar item dalam suatu data set yang ditentukan [2]. Dalam dunia bisnis lazim dikenal istilah affinity analysis. Tugas dari association rule adalah mencari aturan yang tidak mencakup hubungan antara dua atau lebih atribut. Association rule meliputi dua tahap [6]:

1) Mencari kombinasi yang paling sering terjadi dari suatu item set.

2) Mendefinisikan Condition dan Result (untuk conditional association rule).

Dalam menentukan suatu association rule, terdapat suatu interestingness measure (ukuran ketertarikan) yang didapatkan dari hasil pengolahan data dengan perhitungan tertentu [3]. Umumnya ada dua ukuran, yaitu:

1) Support: suatu ukuran yang menunjukkan seberapa besar tingkat dominasi suatu item/item set dari keseluruhan transaksi. Ukuran ini menentukan apakah suatu item/itemset layak untuk dicari confidencenya (misal, dari keseluruhan transaksi yang ada, seberapa besar tingkat dominasi yang menunjukkan bahwa item A dan B dibeli bersamaan).

2) Confidence: suatu ukuran yang menunjukkan hubungan antar 2 item secara conditional (misal, seberapa sering item B dibeli jika orang membeli item A).

Kedua ukuran ini nantinya berguna dalam menentukan interesting association rules, yaitu untuk dibandingkan dengan batasan (threshold) yang ditentukan oleh user. Batasan tersebut umumnya terdiri dari min_support dan min_confidence.

\subsection{Analisis dan Perancangan E-commerce}

\subsubsection{Analisis Isi Informasi}

Informasi yang akan ditampilkan pada aplikasi berbasis web ini adalah informasi tentang produkproduk yang dijual oleh Zakiyah Collection dengan cara menampilkan gambar dan harga dari masingmasing produk seperti songket, blongket, blongsong, tajung dan aksesoris lainnya.

\subsubsection{Analisis interaksi dan fungsional}

Analisis interaksi dan fungsional yang ada dalam E-commerce ini akan digambarkan dalam diagram UML (unified modelling language). Analisis interaksi dan fungsional dalam penelitian ini dapat dilihat pada gambar 1, gambar 2, dan gambar 3 berikut yang memperlihatkan interaksi dan aliran informasi dari customer ke system atau sebaliknya.

1) Use Case Diagram

Pada sistem ini terdapat 7 aktor yang terlibat, baik secara langsng maupun tidak langsung. Use case diagram dalam sistem ini dapat dilihat pada gambar 2 . 


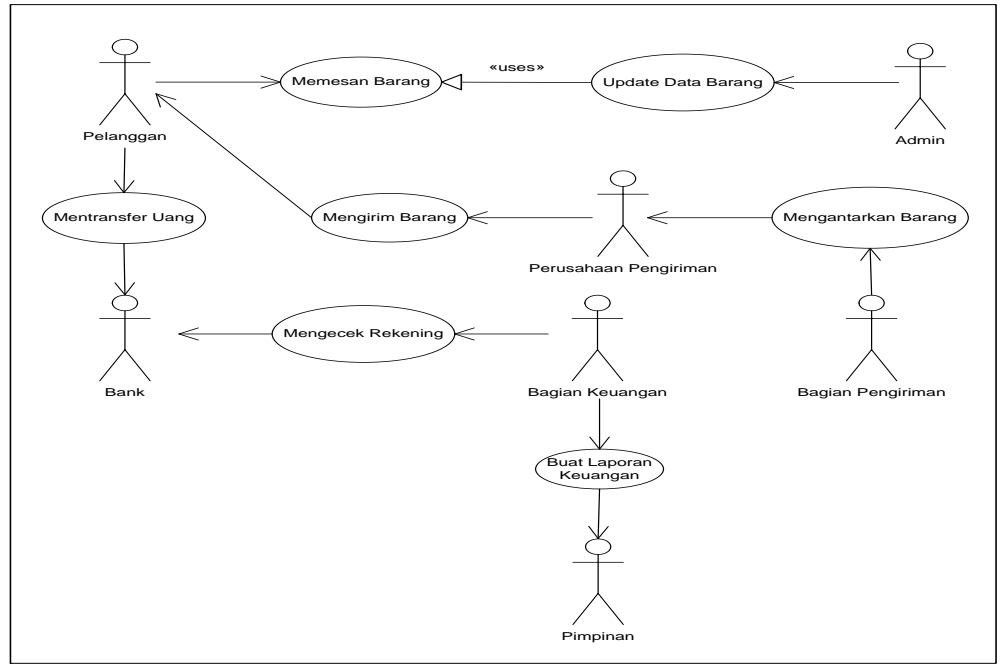

Gambar 2. Use Case Diagram

2) Sequence Diagram

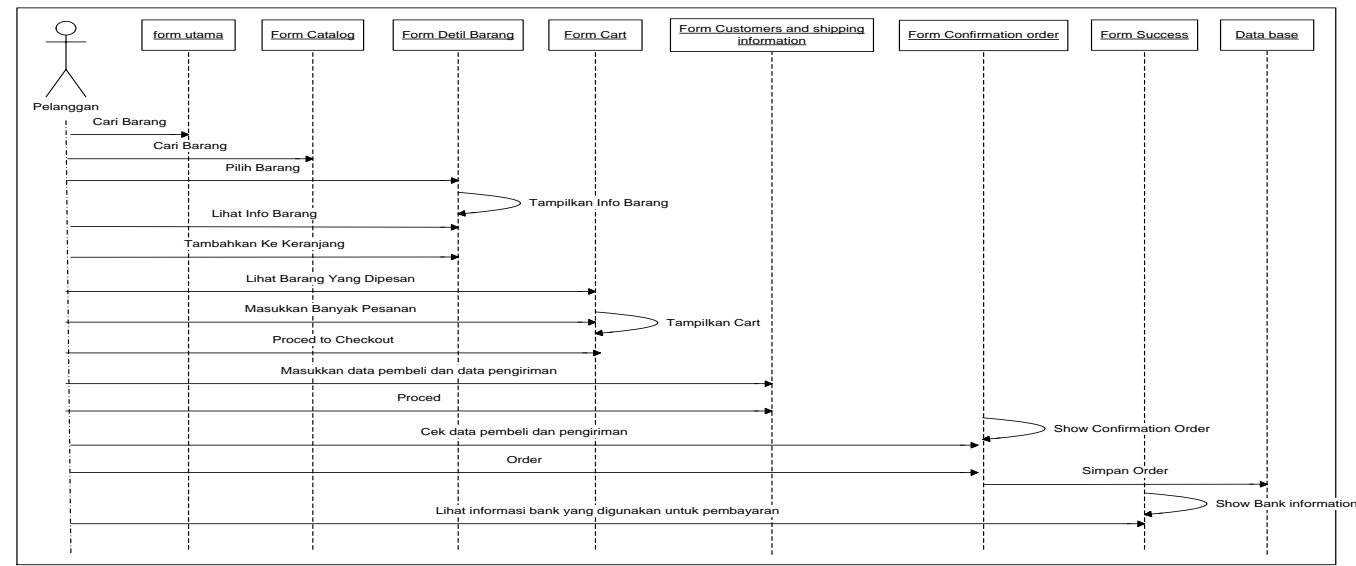

Gambar 3. Sequence Diagram

3) Activity Diagram

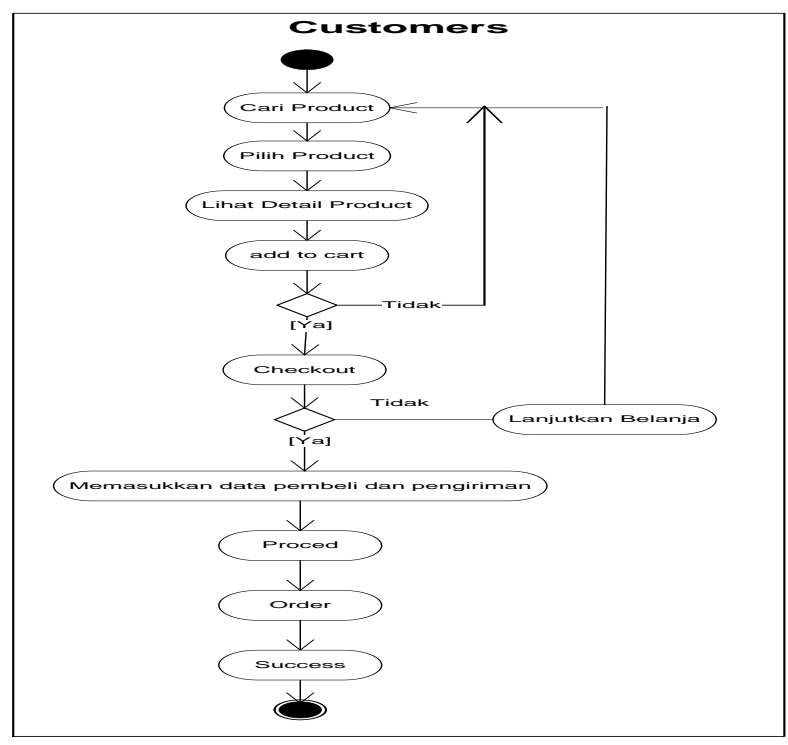

Gambar 4. Activity Diagram 


\section{HASIL DAN PEMBAHASAN}

\subsection{Implementasi E-commerce Zakiyah Collection}

Hasil dari e-commerce yang dilakukan adalah sebuah toko online yang dapat digunakan sebagai sebuah media solusi penjualan secara online sehingga memberikan kemudahan kepada pembeli dalam berkomunikasi dan bertransaksi kepada penjual. Berikut diperlihatkan pada gambar 4 tampilan hasil dari prototype website e-commerce zakiyah collection.
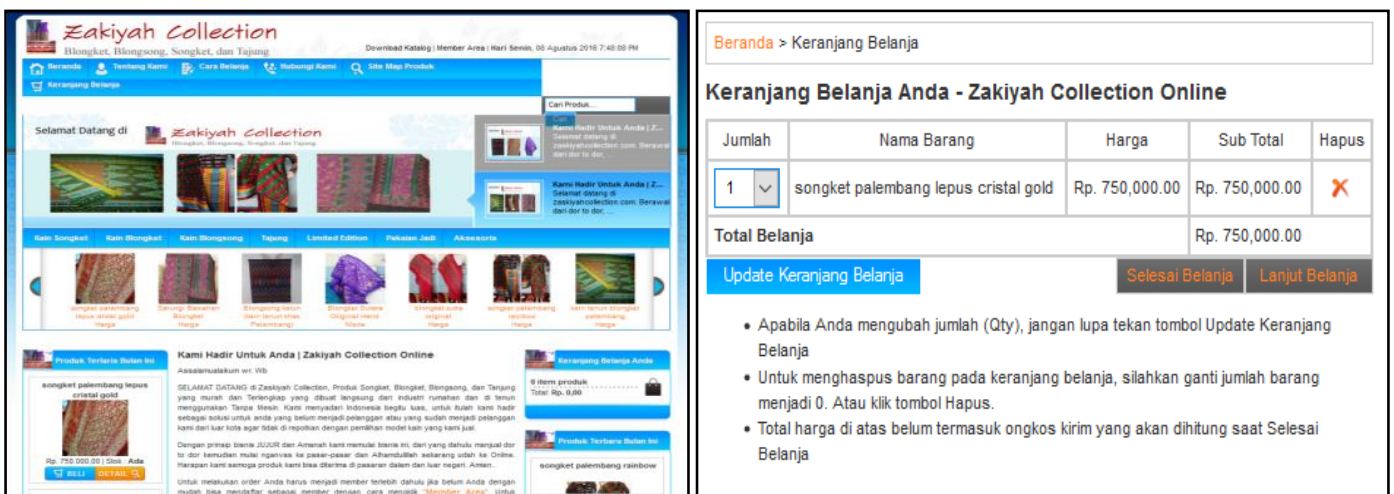

Gambar 4. Halaman Website Zakiyah Collection

\subsection{Analysis Market Basket Zakiyah Collection}

Market basket analysis merupakan sebuah analisis terhadap kebiasaan customer berbelanja pada supermarket dengan cara menemukan asosiasi dan korelasi di antara berbagai macam items yang dimasukkan customer di dalam shopping basket mereka. Secara lebih spesifik Market basket analysis bertujuan untuk mengetahui items apa saja yang sering dibeli bersamaan oleh customers. Items di sini diartikan sebagai berbagai macam produk atau barang pada supermarket.

Analisa data dilakukan dengan menggunakan metode market basket analysis atau association rules. Dua tahapan yang dilakukan adalah menemukan frequent itemset dan membentuk association rules. Pembentukan association rules dilakukan peneliti dengan cara melakukan penghitungan support dan confidence. Proses analisis market basket disini akan dilakukan hanya sebanyak 4 kali kombinasi produk seperti pada tabel 1 berikut.

Tabel 1. Market basket analysis dengan 4 kali kombinasi produk

\begin{tabular}{clll}
\hline Pilih & Jumlah Kombinasi & Threshold Support & Threshold SupportxConfidence \\
\hline$\square$ & 1 Produk & 0.2 & 0.1 \\
$\square$ & 2 Produk & 0.1 & 0.05 \\
$\square$ & 3 Produk & 0.075 & 0.025 \\
$\square$ & 4 Produk & 0.05 & 0.01 \\
$\square$ & 5 Produk & 0 & 0 \\
\hline
\end{tabular}

1) Kombinasi 1 Produk

Tabel 2. Analysis dengan 1 kali kombinasi produk

\begin{tabular}{llll}
\hline Aturan & Support & Confidence & SupportxConfidence \\
\hline If Buy Blongket Then Buy Blongket & 0.5625 & 1 & 0.5625 \\
If Buy Pakaian Jadi Then Buy Pakaian Jadi & 0.5 & 1 & 0.5 \\
If Buy Blongsong Then Buy Blongsong & 0.4375 & 1 & 0.4375 \\
If Buy Tajung Then Buy Tajung & 0.4375 & 1 & 0.4375 \\
If Buy Songket Then Buy Songket & 0.4375 & 1 & 0.4375 \\
If Buy Aksesoris Then Buy Aksesoris & 0.375 & 1 & 0.375 \\
\hline
\end{tabular}

Aturan kombinasi 1 produk berdasarkan nilai support $\mathrm{x}$ confidence terbesar. Hasil yang diperoleh seperti ditunjukkan pada tabel 2 diatas adalah "kemungkinan terbesar jika membeli maka akan membeli blongket dengan nilai 0.5625. jika ada produk blongket dengan merek tertentu kurang laku, maka bisa diletakkan bersebelahan dengan produk dengan merek tertentu yang laku, maka kemungkinan besar akan laku juga". kemudian jika meliha dari aturan kombinasi 1 produk berdasarkan nilai support terbesar, maka hasilnya adalah: 
- Jika 1 produk diletakkan dalam satu etalase atau rak maka kemungkinan besar paling laku adalah blongket dengan nilai 0.5625. Jika ada produk blongket dengan merek tertentu kurang laku, maka bisa diletakkan dalam satu etalase atau rak dengan kelompoknya maka kemungkinan besar akan laku juga.

2) Kombinasi 2 Produk

Tabel 3. Analysis dengan 2 kali kombinasi produk

\begin{tabular}{llll}
\hline Aturan & Support & \multicolumn{1}{c}{ Confidence } & SupportxConfidence \\
\hline If Buy Blongket Then Buy Songket & 0.375 & 0.85714285714286 & 0.32142857142857 \\
If Buy Blongket Then Buy Pakaian Jadi & 0.375 & 0.75 & 0.28125 \\
If Buy Songket Then Buy Blongket & 0.375 & 0.66666666666667 & 0.25 \\
If Buy Pakaian Jadi Then Buy Blongket & 0.375 & 0.66666666666667 & 0.25 \\
If Buy Pakaian Jadi Then Buy Songket & 0.3125 & 0.71428571428571 & 0.22321428571429 \\
If Buy Blongsong Then Buy Tajung & 0.3125 & 0.71428571428571 & 0.22321428571429 \\
If Buy Tajung Then Buy Blongsong & 0.3125 & 0.71428571428571 & 0.22321428571429 \\
If Buy Songket Then Buy Pakaian Jadi & 0.3125 & 0.625 & 0.1953125 \\
If Buy Pakaian Jadi Then Buy Blongsong & 0.25 & 0.57142857142857 & 0.14285714285714 \\
If Buy Blongsong Then Buy Pakaian Jadi & 0.25 & 0.5 & 0.125 \\
If Buy Blongsong Then Buy Aksesoris & 0.1875 & 0.5 & 0.09375 \\
If Buy Tajung Then Buy Aksesoris & 0.1875 & 0.5 & 0.09375 \\
If Buy Pakaian Jadi Then Buy Aksesoris & 0.1875 & 0.5 & 0.09375 \\
If Buy Aksesoris Then Buy Blongsong & 0.1875 & 0.42857142857143 & 0.080357142857143 \\
If Buy Aksesoris Then Buy Tajung & 0.1875 & 0.42857142857143 & 0.080357142857143 \\
If Buy Pakaian Jadi Then Buy Tajung & 0.1875 & 0.42857142857143 & 0.080357142857143 \\
If Buy Tajung Then Buy Pakaian Jadi & 0.1875 & 0.375 & 0.0703125 \\
If Buy Aksesoris Then Buy Pakaian Jadi & 0.1875 & 0.375 & 0.0703125 \\
\hline
\end{tabular}

Aturan kombinasi 2 produk berdasarkan nilai support $\mathrm{x}$ confidence terbesar. Hasil analisis yang diperoleh dari tabel 3 diatas adalah "kemungkinan terbesar jika membeli blongket maka akan membeli songket dengan nilai 0.32142857142857 . Jika ada produk songket dengan merek tertentu kurang laku, maka bisa diletakkan bersebelahan dengan produk blongket dengan merek tertentu yang laku, maka kemungkinan besar akan laku juga". kemudian jika meliha dari aturan kombinasi 2 produk berdasarkan nilai support terbesar, maka hasilnya adalah:

- $\quad$ Jika 2 produk diletakkan dalam satu etalase atau rak maka kemungkinan besar paling laku adalah blongket dan songket dengan nilai 0.375. Jika ada produk blongket atau songket dengan merek tertentu kurang laku, maka bisa diletakkan dalam satu etalase atau rak dengan kelompoknya maka kemungkinan besar akan laku juga.

- $\quad$ Jika 2 produk diletakkan dalam satu etalase atau rak maka kemungkinan besar paling laku adalah blongket dan pakaian jadi dengan nilai 0.375. Jika ada produk blongket atau pakaian jadi dengan merek tertentu kurang laku, maka bisa diletakkan dalam satu etalase atau rak dengan kelompoknya maka kemungkinan besar akan laku juga.

3) Kombinasi 3 Produk

Tabel 4. Analysis dengan 3 kali kombinasi produk

\begin{tabular}{|c|c|c|c|}
\hline Aturan & Support & Confidence & SupportxConfidence \\
\hline $\begin{array}{l}\text { If Buy Blongket And Buy Pakaian Jadi Then } \\
\text { Buy Songket }\end{array}$ & 0.3125 & 0.71428571428571 & 0.22321428571429 \\
\hline $\begin{array}{l}\text { If Buy Songket And Buy Blongket Then Buy } \\
\text { Pakaian Jadi }\end{array}$ & 0.3125 & 0.625 & 0.1953125 \\
\hline $\begin{array}{l}\text { If Buy Pakaian Jadi And Buy Songket Then Buy } \\
\text { Blongket }\end{array}$ & 0.3125 & 0.55555555555556 & 0.17361111111111 \\
\hline $\begin{array}{l}\text { If Buy Blongsong And Buy TajungThen Buy } \\
\text { Aksesoris }\end{array}$ & 0.1875 & 0.5 & 0.09375 \\
\hline $\begin{array}{l}\text { If Buy Tajung And Buy Aksesoris Then Buy } \\
\text { Blongsong }\end{array}$ & 0.1875 & 0.42857142857143 & 0.080357142857143 \\
\hline $\begin{array}{l}\text { If Buy Aksesoris And Buy Blongsong Then Buy } \\
\text { Tajung }\end{array}$ & 0.1875 & 0.42857142857143 & 0.080357142857143 \\
\hline
\end{tabular}




\begin{tabular}{|c|c|c|c|}
\hline Aturan & Support & Confidence & SupportxConfidence \\
\hline $\begin{array}{l}\text { If Buy Blongsong And Buy Pakaian Jadi Then } \\
\text { Buy Aksesoris }\end{array}$ & 0.125 & 0.33333333333333 & 0.041666666666667 \\
\hline $\begin{array}{l}\text { If Buy Tajung And Buy Pakaian Jadi Then Buy } \\
\text { Aksesoris }\end{array}$ & 0.125 & 0.33333333333333 & 0.041666666666667 \\
\hline $\begin{array}{l}\text { If Buy Blongsong And Buy Pakaian Jadi Then } \\
\text { Buy Songket }\end{array}$ & 0.125 & 0.28571428571429 & 0.035714285714286 \\
\hline $\begin{array}{l}\text { If Buy Pakaian Jadi And Buy Songket Then Buy } \\
\text { Blongsong }\end{array}$ & 0.125 & 0.28571428571429 & 0.035714285714286 \\
\hline $\begin{array}{l}\text { If Buy Pakaian Jadi And Buy Aksesoris Then } \\
\text { Buy Blongsong }\end{array}$ & 0.125 & 0.28571428571429 & 0.035714285714286 \\
\hline $\begin{array}{l}\text { If Buy Pakaian Jadi And Buy Blongket Then } \\
\text { Buy Blongsong }\end{array}$ & 0.125 & 0.28571428571429 & 0.035714285714286 \\
\hline $\begin{array}{l}\text { If Buy Pakaian Jadi And Buy Aksesoris Then } \\
\text { Buy Tajung }\end{array}$ & 0.125 & 0.28571428571429 & 0.035714285714286 \\
\hline $\begin{array}{l}\text { If Buy Blongket And Buy Blongsong Then Buy } \\
\text { Pakaian Jadi }\end{array}$ & 0.125 & 0.25 & 0.03125 \\
\hline $\begin{array}{l}\text { If Buy Aksesoris And Buy Blongsong Then Buy } \\
\text { Pakaian Jadi }\end{array}$ & 0.125 & 0.25 & 0.03125 \\
\hline $\begin{array}{l}\text { If Buy Songket And Buy Blongsong Then Buy } \\
\text { Pakaian Jadi }\end{array}$ & 0.125 & 0.25 & 0.03125 \\
\hline $\begin{array}{l}\text { If Buy Blongsong And Buy Tajung Then Buy } \\
\text { Pakaian Jadi }\end{array}$ & 0.125 & 0.25 & 0.03125 \\
\hline $\begin{array}{l}\text { If Buy Aksesoris And Buy Tajung Then Buy } \\
\text { Pakaian Jadi }\end{array}$ & 0.125 & 0.25 & 0.03125 \\
\hline $\begin{array}{l}\text { If Buy Blongsong And Buy Pakaian Jadi Then } \\
\text { Buy Blongket }\end{array}$ & 0.125 & 0.2222222222222 & 0.277777777777778 \\
\hline $\begin{array}{l}\text { If Buy Blongsong And Buy Songket Then Buy } \\
\text { Blongket }\end{array}$ & 0.125 & 0.2222222222222 & 0.277777777777778 \\
\hline $\begin{array}{l}\text { If Buy Tajung And Buy Pakaian Jadi Then Buy } \\
\text { Blongsong }\end{array}$ & 0.125 & 0.28571428571429 & 0.035714285714286 \\
\hline $\begin{array}{l}\text { If Buy Pakaian Jadi And Buy Blongsong Then } \\
\text { Buy Tajung }\end{array}$ & 0.125 & 0.28571428571429 & 0.035714285714286 \\
\hline $\begin{array}{l}\text { If Buy Blongket And Buy Blongsong Then Buy } \\
\text { Songket }\end{array}$ & 0.125 & 0.28571428571429 & 0.035714285714286 \\
\hline $\begin{array}{l}\text { If Buy Songket And Buy Blongket Then Buy } \\
\text { Blongsong }\end{array}$ & 0.125 & 0.28571428571429 & 0.035714285714286 \\
\hline
\end{tabular}

Aturan kombinasi 3 produk berdasarkan nilai support $x$ confidence terbesar. Hasil yang diperoleh dari analisis pada tabel 4 diatas adalah "kemungkinan terbesar jika membeli blongket dan pakaian jadi maka akan membeli songket dengan nilai 0.22321428571429. Jika ada produk songket dengan merek tertentu kurang laku, maka bisa diletakkan bersebelahan dengan produk blongket dan pakaian jadi dengan merek tertentu yang laku, maka kemungkinan besar akan laku juga". Kemudian jika meliha dari aturan kombinasi 3 produk berdasarkan nilai support terbesar, maka hasilnya adalah:

- $\quad$ Jika 3 produk diletakkan dalam satu etalase atau rak maka kemungkinan besar paling laku adalah blongket dan pakaian jadi dan songket dengan nilai 0.3125 . jika ada produk blongket atau pakaian jadi atau songket dengan merek tertentu kurang laku, maka bisa diletakkan dalam satu etalase atau rak dengan kelompoknya maka kemungkinan besar akan laku juga.

4) Kombinasi 4 Produk

Tabel 5. Analysis dengan 3 kali kombinasi produk

\begin{tabular}{|c|c|c|c|}
\hline Aturan & Support & Confidence & SupportxConfidence \\
\hline $\begin{array}{l}\text { If Buy Blongsong And Buy Tajung And } \\
\text { Buy Pakaian Jadi Then Buy Aksesoris }\end{array}$ & 0.125 & 0.33333333333333 & 0.041666666666667 \\
\hline $\begin{array}{l}\text { If Buy Pakaian Jadi And Buy Songket } \\
\text { And Buy Blongket Then Buy Blongsong }\end{array}$ & 0.125 & 0.28571428571429 & 0.035714285714286 \\
\hline $\begin{array}{l}\text { If Buy Blongket And Buy Blongsong } \\
\text { And Buy Pakaian Jadi Then Buy Songket }\end{array}$ & 0.125 & 0.28571428571429 & 0.035714285714286 \\
\hline $\begin{array}{l}\text { If Buy Tajung And Buy Pakaian Jadi And } \\
\text { Aksesoris Then Buy Blongsong }\end{array}$ & 0.125 & 0.28571428571429 & 0.035714285714286 \\
\hline
\end{tabular}




\begin{tabular}{llll}
\hline Aturan & Support & \multicolumn{1}{c}{ Confidence } & SupportxConfidence \\
\hline $\begin{array}{l}\text { If Buy Pakaian Jadi And Buy Aksesoris } \\
\text { And Buy Blongsong Then Buy Tajung }\end{array}$ & 0.125 & 0.28571428571429 & 0.035714285714286 \\
$\begin{array}{l}\text { If Buy Songket And Buy Blongket And } \\
\text { Buy Blongsong Then Buy Pakaian Jadi }\end{array}$ & 0.125 & 0.25 & 0.03125 \\
$\begin{array}{l}\text { If Buy Aksesoris And Buy Blongsong } \\
\text { And Buy Tajung Then Buy Pakaian Jadi }\end{array}$ & 0.125 & 0.25 & 0.03125 \\
$\begin{array}{l}\text { If Buy Blongsong And Buy Pakaian Jadi } \\
\text { And Buy Songket Then Buy Blongket }\end{array}$ & 0.125 & 0.2222222222222 & 0.277777777777778 \\
\hline
\end{tabular}

Aturan kombinasi 4 produk berdasarkan nilai support $x$ confidence terbesar. Hasil yang diperoleh dari hasil analisis pada tabel 5 adalah "kemungkinan terbesar jika membeli blongsong dan tajung dan pakaian jadi maka akan membeli aksesoris dengan nilai 0.041666666666667 . Jika ada produk aksesoris dengan merek tertentu kurang laku, maka bisa diletakkan bersebelahan dengan produk blongsong dan tajung dan pakaian jadi dengan merek tertentu yang laku, maka kemungkinan besar akan laku juga". Kemudian jika meliha dari aturan kombinasi 4 produk berdasarkan nilai support terbesar, maka hasilnya adalah:

- $\quad$ Jika 4 produk diletakkan dalam satu etalase atau rak maka kemungkinan besar paling laku adalah blongsong dan tajung dan pakaian jadi dan aksesoris dengan nilai 0.125. Jika ada produk blongsong atau tajung atau pakaian jadi atau aksesoris dengan merek tertentu kurang laku, maka bisa diletakkan dalam satu etalase atau rak dengan kelompoknya maka kemungkinan besar akan laku juga.

- $\quad$ Jika 4 produk diletakkan dalam satu etalase atau rak maka kemungkinan besar paling laku adalah pakaian jadi dan songket dan blongket dan blongsong dengan nilai 0.125. jJka ada produk pakaian jadi atau songket atau blongket atau blongsong dengan merek tertentu kurang laku, maka bisa diletakkan dalam satu etalase atau rak dengan kelompoknya maka kemungkinan besar akan laku juga.

\section{KESIMPULAN}

Dari pembahasan sebelumnya dapat diambil kesimpulan yang berkaitan dengan hasil sebagai berikut:

1) Website zakiyah collection yang berbasis e-commerce yang dibuat memberikan kemudahan kepada para pembeli dalam memilih produk yang diharapkan seperti songket, blongket, blongsong, tajung, dan asesoris yang dijual.

2) Dengan menggunakan association rule analysis yang ada didalam market basket analysis dapat diketahui hubungan antar item produk yang dijual di zakiyah collection dalam suatu data set dan menampilkannya dalam bentuk asssociation rules. Association rule akan meng-capture transaksi jual beli yang ada di zakiyah collection dalam data yang berukuran besar.

3) Dalam proses analisinya, dilakukan 4 kali kombinasi produk yang berdasarkan nilai support $\mathrm{x}$ confidence terbesar dengan hasil berupa angka-angka kemungkinan transasksi yang berkaitan dengan produk yang dijual.

\section{DAFTAR PUSTAKA}

[1] Albion Research $\quad$ Ltd., $2007 . \quad$ Market Basket http://www.albionresearch.com/data_mining/market_basket.php (diakses tanggal 08 Agustus 2016).

[2] Han, Jiawei dan Kamber, Micheline., 2006. Data Mining: Concept and Techniques Second Edition, Morgan Kaufmann Publishers.

[3] Muzakir, Ari., 2014. "Analisa Dan Pemanfaatan Algoritma K-Means Clustering Pada Data Nilai Siswa Sebagi Penentuan Penerima Beasiswa”, Prosiding Seminar Nasional Aplikasi Sains \& Teknologi, Istitute Sains dan Teknologi AKPRIND Yogyakarta, hal. A-195.

[4] Sukmadinata. (2006). Metode Penelitian Pendidikan, Remaja Rosdakarya, Bandung.

[5] Triton PB. (2006). Mengenal e-commerce dan bisnis di dunia cyber. Yogyakarta. Argo Publisher.

[6] Ulmer, David, 2002. "Mining an Online Auctions Data Warehouse." The MidAtlantic Student Workshop on Programming Languages and Systems. Pace University. http://csis.pace.edu/csis/masplas/p8.pdf. Diakses tanggal 09 Agustus 2016 